\title{
Is my professional future biased for gender perceptions? A study for the Spanish case with public policy proposals on education
}

\author{
¿Está mi futuro profesional sesgado por las \\ percepciones de género? \\ Un estudio para el caso español con propuestas de \\ políticas públicas sobre educación
}

\author{
IsABel Novo-CoRTI ${ }^{1}$ \\ Nuria Calvo ${ }^{2}$ \\ Laura Varela-CANDAmio ${ }^{3}$ \\ Universidade da Coruña (España)
}

Recibido el 11 de septiembre de 2015, aceptado el 26 de octubre de 2016

Publicado online el 19 de julio de 2017

$\mathrm{N}^{\mathrm{o}}$ de clasificación JEL: I2, J7

DOI: $10.5295 / \mathrm{cdg} .150578 \mathrm{in}$

\begin{abstract}
:
This article deals with the 'glass ceiling' phenomenon based on the fact that a disproportionately low number of women access managerial positions by analyzing gender differences in the 'educational profile' and 'professional profile perceived'. The sample is conducted among 165 undergraduate economics students (54 males and 111 females) in the final year of college in Spain at the time they were planning their future professional career. The methodology used is based on two approaches. First, an analytic model using Structural Equations Model (SEM) that leads us to explore perceptual differences in favorite subjects, professional ambitions, values associated to the workplace and mobility. Second, a causal analysis following the System Dynamics methodology to describe the women's behavior in explaining their self-exclusion from managerial positions. Findings confirm the existence of an educational system biased by gender and reveals that while men are more ambitious professionally and show greater capacity to geographical mobility, women require greater motivation at work. Moreover, we find that the factors explaining why women are still far from reaching senior management positions are both external (gender stereotypes or organizational policies) and internal ones (self-confidence, self-esteem). Finally, we propose a set of education measures as a starting point to implement public policies which could reduce women's barriers to break their glass ceiling.
\end{abstract}

\footnotetext{
${ }^{1}$ Department of Economics, Economic Development and Social Sustainability Group (EDaSS), Faculty of Economics and Business, Campus de Elviña s/n, 15071, A Coruña (Spain), isabel.novo.corti@udc.es

${ }^{2}$ Department of Business, Jean Monnet Group of Competence and Development (C+D), Faculty of Economics and Business, Campus de Elviña s/n, 15071,A Coruña (Spain), nuria.calvob@udc.es

${ }^{3}$ Department of Economics,Jean Monnet Group of Competence and Development (C+D) and RIFDE, Faculty of Economics and Business, Campus de Elviña s/n, 15071, A Coruña (Spain), laura.varela.candamio@udc.es
} 


\section{Keywords:}

Glass ceiling, gender, social stereotypes, public policy, education, labor market.

\section{Resumen:}

Este artículo trata el fenómeno del techo de cristal basado en el hecho de que un desproporcionado bajo número de mujeres accede a puestos de trabajo de dirección y gestión a través del análisis de las diferencias de género en el perfil educativo y el perfil profesional percibido. La muestra se realizó entre 165 alumnos y alumnas (54 hombres y 111 mujeres) cursando disciplinas relacionadas con la economía en su último año de universidad en España mientras planeaban su futura carrera profesional. La metodología utilizada está basada en dos enfoques. Primero, un modelo analítico usando un modelo de ecuaciones estructurales (SEM) que nos permite explorar las diferencias perceptuales en cuanto a asignaturas favoritas, ambiciones profesionales, valores asociados con el lugar de trabajo y movilidad laboral. Segundo, un análisis causal siguiendo la metodología de la Dinámica de Sistemas para describir el comportamiento de las mujeres que justifica su auto-exclusión en los puestos directivos. Los resultados confirman la existencia de un sistema educativo sesgado por género y revela que mientras los hombres son más ambiciosos profesionalmente y con mayor capacidad para la movilidad geográfica, las mujeres requieren una mayor motivación en el trabajo. Además, hemos descubierto que los factores que explican el por qué las mujeres siguen estando alejadas de los altos puestos directivos son tanto causas externas (estereotipos de género o políticas organizativas) como causas internas (autoconfianza, autoestima). Finalmente, proponemos un conjunto de medidas educativas como punto de partida para implantar políticas públicas que podrían reducir las barreras de las mujeres y romper así su techo de cristal.

\section{Palabras clave:}

Techo de cristal, género, estereotipos sociales, política pública, educación, mercado laboral. 


\section{INTRODUCTION}

The human capital of companies, consisting of a set of reasoning and decision-making skills, abilities and knowledge, is the foundation for business competition (Rumelt 1987; Conner 1991; Grant 1996). Specifically, in advanced countries, women's economic participation is essential not only in terms of fairness and equality but also as a strategic issue for key goals like economic development, social cohesion and life quality (Barrientos 2001; Levin 2003). The number of professionally qualified women in education and business has been constantly increasing in the last decades but their presence in senior positions is still quite low. This phenomena, called glass ceiling effect, implies that gender is stronger at the top of the hierarchy than at lower levels and that these disadvantages become worse later in a person's career (Cotter et al. 2001) and still persist as an international social reality in all sectors of the economy ${ }^{4}$ Hymowitz and Schellhardt 1986; Morrison and von Glinow 1990).

These difficulties for promotion and job development for women have been widely known throughout history (Reskin and Roos 1990; Cullen and Lunab 1993; Ridgeway 2001; Shalev 2009). However, what are the main obstacles that women usually face to achieve senior positions? A branch of the literature tried to explain this situation by analyzing gender differences in leadership styles, as a cultural construct (0'Sullivan 1999). While men's leadership style can be described as transactional and result-oriented through a strict control, women's style is transformational and based on social sensitivity and collaboration (Rosener 1995; Reskin y McBrier 2000). On the other hand, other authors (Wajcman 1998; Fischer et al. 2001) state that what determines management leadership styles is 'male-orientated organizational expectations', i.e., the traditional men's manager power and self-perception as well as men-organizational structure and policies (Cullen and Lunab 1993) ${ }^{5}$. Along with this, the Role Congruity Theory of Prejudice (Eagly and Karau 2002) affirms that prejudice towards female leaders stems from the incongruity perceived between female characteristics and the requirements of the role of the leader into three direct consequences: a) less favorable attitudes, b) bigger obstacles to reach management positions and c) bigger difficulties to be recognized as efficient leaders. In the case of Spain, the role congruity theory is particularly consistent and represents a real problem among students of this country. Thus, in a comparison between male and female students from the United States and Spain, U.S. students perceived the roles as more possible than Spanish students did and also men perceived these roles as more positive than women did only in Spain (Killeen et al., 2006). More recently, Garcia-Retamero and López-Zafra (2009) tested participants in Germany and Spain evaluating a male or a female candidate for a leadership position. Results revealed that Spanish participants showed more prejudice against the female candidate than German participants did. Moreover, whilst German

\footnotetext{
${ }^{4}$ The glass ceiling effect is more pronounced in the case of large companies where only $10 \%$ of managerial positions are women against $22 \%$ in small companies (German Institute for Economic Research -DIW).

${ }^{5}$ Moreover, other studies analyzed gender differences with regard to self-perception of the manager role. While women perceived leadership as an opportunity for personal fulfillment and as a stressful situation, men perceived leadership as an opportunity for exerting power and therefore they are more determined to hold managerial positions (Molero Alonso et al. 2009).
} 
participants made an internal causal attribution to explain the female success, Spanish participants sometimes made an external causal attribution.

Then, what happens if we are looking for the causes of the glass ceiling effect in external sources, as the organizational hierarchy of the society in general, when the main reason is related to the previous perception' patterns of the individuals? Given these striking differences in the vocational and educational behaviors in males and females, Jackeline Eccles Parsons (1994) develops a comprehensive model of achievement-related choices associated with decision making whose outstanding findings reveal two sets of beliefs directly related with this problem: the individual's expectations for success based on the confidence in their own intellectual ability and the value the individual attached to the various options perceived. This model justifies the relation of these beliefs to cultural norms, experiences, aptitudes and to those personal attitudes that are commonly assumed to be associated with achievement activities. In this context, "one answer should be to focus more on work gender stereotyping and attitude changing at a young age (OECD 2012, p.5)". Following this approach, another branch of the literature identifies gender differences in attitudes of the higher education students. Anastasia et al. (1999) found the following items rated by women students as higher in importance than those in males: awareness of career opportunities; career counseling; getting the degree in a short term; opportunities to mature and support of the teacher inside and outside the classroom.

Nowadays, despite the relatively successful performance of women in the educational system of developed countries, this trend is not clearly reflected in the top level positions at organizations. This situation, called the 'unsolved problem' (Fernández Enguita 2004), can be explained by the weight of other responsibilities assumed by women from an early age, which may have an impact on their professional development. Since professionals usually reach the management positions after a bunch of years of work, the self-exclusion of women of the run for promotion would explain that women do not reach the top positions at organizations spite of a better qualification and a similar insertion in the job market. Women are under-represented in science, technology, engineering and mathematics in most industrialized countries (Blickenstaff 2005), but the women's absence in the top-managerial positions is especially surprising in the case of social sciences, where women have a strong presence and get growing academic success (Bradley 2000, Graf 2005). In fact, women held only $14.3 \%$ of the board-member positions of large listed companies in 2013 in Spain compared with $16.6 \%$ as the average of the EU-27, and even $23.6 \%$ in the Netherlands and $20.5 \%$ in Germany (EUROPEAN COMMISSION 2013). Following this approach, Mehta et al. (2003) interviewed female students between 22 and 30 years old to analyze the perceived vision of being a female graduate student in social sciences in the USA and the UK. Female students revealed as advantages the fact of receiving more lenient treatment from faculty and as disadvantages the fact of being viewed in terms of stereotypical gender roles and receiving unwanted sexual attention. In this sense, for instance, Ventura Fernández and Quero Gervilla (2013) use a structural equation model among college students to demonstrate significant differences in entrepreneurial behavior patterns according to gender, identifying a more complex process in need of external support among women compared to men's.

In 2007, Colander and Holmes developed a study on the most important USA universities, providing strong evidences why women are less satisfied with their education in 
Economic disciplines and why these also discourage female participation in the academic field than their male counterparts ${ }^{6}$. These authors report gender differences in the demographics, satisfaction and academic integration of economics graduate students yielded a wealth of information about the graduate students' backgrounds, interests and perceptions of their experiences in these top programs, according to the following ten items: demographics of $\mathrm{PhD}$ candidates in Economics; reasons given for the decision to attend graduate school; elements of graduate school that have been "very stressful"; activities engaged in, besides studying; major factor in choice of dissertation topic; fields "of great interest"; most interesting type of article; characteristics that students deem "very important" in increasing the likelihood that students are placed on the fast track; career plans and finally satisfaction with graduate school. Their results suggest that the emphasis on theoretical studies in the core of the graduate economics program might have an indirect connection with the type of work that applied policy students will be doing once they graduate. This fact jointly with the stress suffered by women when it comes to economics disciplines could discourage them from continuing in economics with the consequent cost for women with great creative promise, which do not benefit nearly as much as they would have from more policy-driven core courses.

In this paper, we adapted the survey of the aforementioned study to analyse gender differences observed in students through exploring unobserved perceptual differences in several factors that involve both external motives (gender stereotypes or organizational policies) and internal motives (self-confidence, self-esteem). The methodology used includes two approaches, an analytic analysis and a causal analysis. The first one explores the perceptual differences in the educational profile (favorite subjects) and professional profile perceived (professional ambitions, values associated to the workplace and mobility) of the students through a structural equation model (SEM). The second one implies a causal analysis showing the women's behavior that leads them to their self-exclusion from managerial positions through the Dynamic Systems methodology. Findings reveal that while men are more ambitious professionally and with more capability for mobility, women require social motivation at work. Moreover, we find that the factors explaining why women are still far from reaching senior management positions are both external (gender stereotypes or organizational policies) and internal ones (self-confidence, self-esteem). Therefore, the implantation of some educational measures by the policy makers are proposed to avoid a professional future biased for gender perceptions.

The paper is structured as follows. Section 2 offers a theoretical review of the gender equality policies applied in Spain to the context of economy and business and their effects over the education system and the job expectations. Section 3 introduces the contextual framework and the hypotheses proposed in our case study. Section 4 describes the method used in the study, specifying the participants, the procedure, the instrument and the data analysis. Section 5 presents the outcomes of the study. Section 6 describes the implications of the results obtained and propose some solutions in the Spanish educational field. Finally, Section 7 concludes the study and summarizes the main results of the paper.

\footnotetext{
${ }^{6}$ The universities included in their analysis were Harvard, Stanford, Princeton, Yale, Massachusetts Institute of Technology (MIT), Columbia and Chicago.
} 


\section{GENDER DIFFERENCES IN SPAIN}

The characteristics of women's leadership serve the concerns and development needs of its employees, the vision of the challenges in a more comprehensive manner and the ability to arise passion and inspire those directed to conduct an additional effort to achieve organization goals. These are the traits that define a transformational leader. Several studies show that, in general, transformational leadership inherent in women is key in business organization to the members displaying an attractive future for the business, building a team spirit through enthusiasm, optimism and self-determination. Moreover, women tend to be natural transformational leaders in the sense that they often seek to interact with their employees, promote the participation of all, share power and information, increasing self-esteem of others and arousing passion and inspire those who lead (Matsa and Miller 2013). Specifically, in times of crisis, it has been stated that women are naturally able to manage stress, take responsibility for their own mistakes and promote a climate of trust among its employees. This is what experts call the association "think-Crisis-think female" (Ryan et al. 2011) or "think crisis- think women" during extreme situations. Thus, the presence of women on boards is usually related to a number of positive consequences, among which we can point out improved organizational performance, more ethical and better performance in the field of corporate social responsibility and other similar practices (Joy et al. 2007).

Therefore, gender roles are changing in and out of the business and, slowly, society is beginning to formally recognize the importance of women in the labor and business world. Nowadays, we are more aware of the benefits of complementarity between men and women in leadership and government of all kinds of businesses, including family. As women, this awareness offers a wide range of possibilities to enrich and revitalize the general business environment. As a consequence, the reinforcement of equal access to employment for men and women have been promoted in the UE in the last years, especially in countries as Spain, where women position in the labour market still depends, to a big extent, on the decisions taken by the authorities and the public policies carried out (Kiaušienè and Streimikiene 2013). These policies (maternity leave, part-time jobs, training courses or fiscal incentives), despite being good for a government's image and help companies to come across as socially responsible, do not strategically tackle the barriers of access to managerial positions embedded in organizational systems (Loderstedt 2005; Rottenberg 2014). Consequently, governments fail to integrate women on all labour force levels (Alemagno and Dickie 2005).

The case of Spain is especially interesting due to the extraordinary cultural change produced in barely fifty years. In the 1960`s, Spain was a mostly agricultural country with very traditional structures which needed to be modernized with qualified professionals. The higher demand of formal education (supported by demographic growth and middle-class growth) together with the gradual participation of women into the workforce, led the way to a revision of education. Moreover, the goal of gender equality in education was supported by pro-equality budgets and government policies which have sparked changes both in social behavior and new legal guidelines (González-González et al. 2011). Since it was widely accepted that investing in education was a synonym for progress, a new educational system was designed with the slogan "education for all" to integrate women into the 
production system. In this sense, skills and education should have improved the women chances of having successful professional careers but due to the persistence of traditional values in the Spanish society those women entered the workforce part-time or directly quit after a while (González Pérez 2010) revealing that family responsibilities are the main source of this neglect (Daley 1996).

The gender equality policies, initiated in the educational frame, progressively expanded to the labor market. The most significance regulatory framework to boost equality policies in Spain appeared in 2007 through the Law 3/2007 ${ }^{7}$ where companies were obliged to consider equal opportunities for men and women as a pattern to follow. This law became the most ambitious legal frame of Europe in gender equity. As a result, the integration of women into the workforce has been steady in recent years, spite of the economic crisis that was initiated in 2008 (Figure 1). Although a clear trend towards convergence of female and male employment rates is observed, these results do not match the gender balance with regards to high-responsibility positions within the field of economy and business.

Figure 1

\section{Employment rates for men and women}

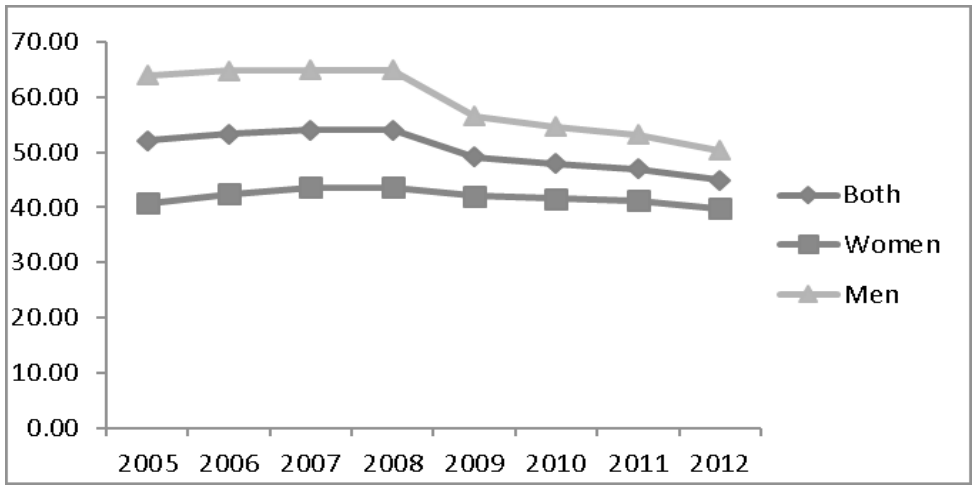

Source: Encuesta de Población Activa. National Institute of Statistics. Retrieved on March 3, 2013 from http:// www.ine.es/inebaseDYN/epa30308/epa_inicio.htm

Figure 2 deals with the presence of women both in public and private company management positions in Spain. The percentage of women in these positions is still lower than that of men and it does not seem to follow the upward trend of the female employment rate. Paradoxically, since Law 3/2007 was enforced, the number of women in managerial positions not only has not varied at all, but it has decreased.

\footnotetext{
${ }^{7}$ Law 3/2007 of 22 March for effective equality of women and men (BOE-A-2007-6115)
} 
Figure 2

Management positions for men and women

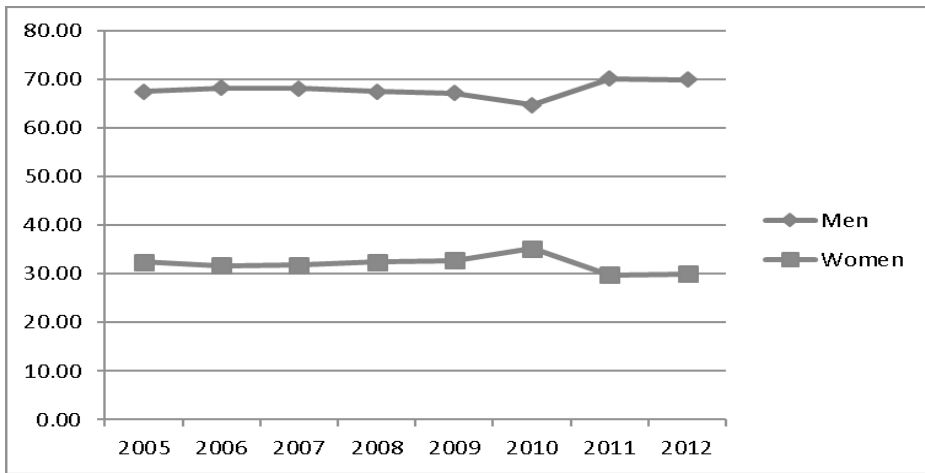

Source: Encuesta de Población Activa. National Institute of Statistics. Retrieved on March 3, 2013 from http:// www.ine.es/inebaseDYN/epa30308/epa_inicio.htm.

Thus, although public institutions, (following the international policies for promotion of equality in society, family and work) try to reinforce the social behaviours to promote gender equality in all spheres of life, something is missing to explain the lack of women in the top positions of the business organizations (OECD 2012). This is especially dramatic in the case of Spain where the development of gender equality has differed from other European countries and the United States, with other historical backgrounds. Thus, Hernández-Bark et al. (2014) summarize the current theoretical and empirical literature on gender and leadership in Spain revealing huge weakness in four essential aspects: (a) the underlying mechanism of gender inequality (e.g., traditional gender roles), (b) gender and leadership behavior, (c) the relation of female representation in top management and on boards with organizational performance, and d) female representation and non-performance-related organizational outcomes. These authors suggest that the current economic and financial crisis might provide a unique opportunity to conduct longitudinal studies to examine the development of gender roles and stereotypes over time in order to create, on the one hand, a more detailed picture of those aspects during the crisis which affect the gender roles themselves and, on the other, those aspects which affect the changes in relation to gender quality, since there is a lack of research regarding this crucial issue. According to the above, this study tries to advance in the analysis of the reasons explaining the different gender roles and the roots of inequality in managerial employment for women in Spain from a multiple perspective within the current crisis.

\section{THE CURRENT RESEARCH}

In this paper, we adapt the survey of Colander and Holmes (2007) in order to study and evaluate the gender roles observed in students through exploring unobserved perceptual factors that might justify the glass ceiling phenomena. The aim of this paper is twofold. 
On the one hand, we develop a structural equation model (SEM) exploring the perceptual differences in the educational profile (favorite subjects) and professional profile perceived (professional ambitions, values associated to the workplace and mobility) of the students. On the other hand, the next stage implies a causal analysis showing the women's behavior that lead them to their self-exclusion from managerial positions through the Dynamic Systems methodology. In this sense, a dynamic causal analysis disentangles new reasons to explain the self-exclusion of women from top positions at organizations through the interaction of two dynamic behaviors: the initial expectations loop and the pre-manager loop. Therefore, the novelty of this study is based on the explanation of the glass ceiling effect as consequence not only of external sources such as social stereotypes or organizational policies but also of the different personal attitudes in the 'educational profile' and 'professional profile perceived' by students, developed along their learning environment. This paper is also innovative from a methodological point of view since we employ a 'double check' method, combining both the Structural Equation Model (SEM) and Dynamic Systems, in order to analyze the gender role and the gender inequalities in the business environment through the interaction of external (gender stereotypes or organizational policies) and internal factors (self confidence and self-esteem).

In response to these data we suggest three hypotheses. The first, the mismatch hypothesis, is related to whether the different gender perceptions embeded in the Spanish academic environment could have an influence on the future difficulties faced by women to be promoted to managerial positions because they are not as well matched to the type of economics currently being taught in Spanish graduate schools that deemphasizes applied and policy-related economics. The second is the Congruity Theory Model hypothesis which holds that the self-exclusion of women of the managerial career is due to the interaction of both psychological (internal factors) and sociological (external and contextual factors) drivers. The third explanation, the stereotype threat hypothesis, proposes that women as a group have been previously stereotyped as being less capable than men.

Once described the above hypotheses, we formulate the following related questions: What are the main psychological and sociological factors revealed by Spanish undergraduate students which discourage women from top-managerial positions? What is the dynamic causal analysis of the women's self-barriers for assuming managerial positions? Is there any measure in the educational system that can break this dynamic? In the next sections we give some answers to all these questions.

\section{METHOD}

This paper analyses the gender differences observed in 165 students enrolled in economic disciplines at the University of A Coruña (Spain) through exploring unobserved perceptual differences in favorite subjects, professional ambitions, values associated to the workplace and mobility. According to all these aspects, we first present the results obtained from the questionnaire adopted from Colander and Holmes (2007) and distributed among the Spanish students. For our analysis purposes we use two different approaches. First, the factorial analysis through the structural equation model (SEM) whose main purpose is to examine unobserved variables through the observed ones and its relationships. The 
use of SEM was pioneered by Wright (1921), using a 'path diagram', and subsequently popularized by Jöreskog and Sörbom (1982) also using factor analysis. This methodology is a valuable tool in social science research because it allows the estimation of multiple dependence and crossed relationships (Hair et al. 1998). We use statistical software AMOS software (Analysis of Moment Structures) linked to the SPSS IBM statistics 21 program to build the factorial model. Second, we raise a causal analysis that allows us to understand the relationship between psychological, sociological and contextual factors in discouraging women from assuming managerial positions. To do so, we elaborate a causal analysis following the System Dynamics methodology (Starman 2000) to describe three loops of women's behavior in order to evaluate the dynamics of the self-exclusion of women from managerial positions.

\subsection{Participants}

The survey was conducted among 165 students in the last course offered by the Faculty of Economics and Business Administration at the University of A Coruña among three different degrees: Economics (5-years duration), Business (3-years duration) and Management and Business Administration (5-years duration) along May and June, 2010 ${ }^{8}$. The description of the sample structure is contained in Table 1.

Since our research required students to have a complete knowledge of all the core subjects of the degree, we chose those students who were in their last year of their degrees. Morover, we selected only students from their final year of college because they were planning their future professional career by the time we collected the information and the patterns of their behavior related to their professional profile perceived have already been developed along the educational stages. This analysis is also particularly timely since this academic year coincides with the change of the curriculum design for studies in Economy required for the European Space of Higher Education and, according to Hernández-Bark et al. (2014), the current economic and financial crisis might provide a unique opportunity to conduct longitudinal studies to examine the development of gender roles and stereotypes over time.

The opportunities of access to the labor market of women rely heavily on the private, public, political, social and educational scenarios. Therefore, it is necessary to know what these characteristics of young women students at universities are in order to improve living conditions for women and those around them. Then, public educational policies must be analyzed from a gender perspective based on these sociodemographic characteristics (Martínez Gómez et al., 2010).

The sample includes a population segment made up of young men and women university students from the Faculty of Economics and Business of the municipality of A Coruña, a region located in the northern of Spain. Indeed, most university students entering the university under study are resident in the province of A Coruña. A descriptive study was analyzed through a socioeconomic and demographic survey in order to ensure their representation with respect to the population under study.

At a provincial level, among the total population in A Coruña, 50.65\% are women (INE, 2010) equivalent to 595,140 people. Among them, young women aged between 21 and 23

\footnotetext{
${ }^{8}$ The results of these surveys can be provided upon request.
} 
correspond to 16,920 women (49.28\%), although the number of women has a similar percentage for all other age groups. In addition, in A Coruña, among all people entering and graduating from university degrees described, $60 \%$ are women but their access to senior positions is still very low.

Table 1

Sample structure

\begin{tabular}{|c|c|c|}
\hline VARIABLE & CATEGORY & $\%$ \\
\hline \multirow{3}{*}{ Gender } & Men & 32.32 \\
\hline & Women & 67.68 \\
\hline & Total & 100.00 \\
\hline \multirow{4}{*}{ University Studies } & Management and Business Administration (5years) & 21.22 \\
\hline & Economics & 10.30 \\
\hline & Business (3years) & 68.48 \\
\hline & Total & 100.00 \\
\hline \multirow{5}{*}{ Age } & $18-20$ & 21.95 \\
\hline & $21-23$ & 51.83 \\
\hline & $24-26$ & 21.34 \\
\hline & $>27$ & 4.88 \\
\hline & Total & 100.00 \\
\hline \multirow{6}{*}{ Father's Educational level } & None & 0.61 \\
\hline & Primary & 42.07 \\
\hline & Secondary & 38.41 \\
\hline & University & 18.30 \\
\hline & Doctorate & 0.61 \\
\hline & Total & 100.00 \\
\hline \multirow{6}{*}{ Mother's Educational level } & None & 0.61 \\
\hline & Primary & 44.51 \\
\hline & Secondary & 40.85 \\
\hline & University & 12.81 \\
\hline & Doctorate & 1.22 \\
\hline & Total & 100.00 \\
\hline Sample & Total & 100.00 \\
\hline
\end{tabular}

Source: Data collected by the authors.

Regarding university students, data show that eight of ten graduates in the A Coruña campus are defined as potential workers, but from these, only $66.2 \%$ got a job twelve months after graduation. However, the employment rate varies depending on the type of degree. Thus, although the average salary stood at 1,116 euros per month and only $24 \%$ of graduates have a permanent labor contract, in the case of the university degrees in our study, the permanent contract is much more common among them. By gender, the only data 
available refers to the percentage difference among types of contract being the temporary contract the only one that has a higher percentage in the case of women $(+11.20 \%)$ (UDC 2010).

Curricula programs of this Spanish educational institution (Faculty of Economics and Business) are made to prepare graduates to access jobs of medium or high responsibility in any company. Their versatile training allows them to coordinate, control, organize, manage and plan action programs and the general policy of a company. As a professional opportunities, they may develop their professional activity in the areas of accounting, marketing, sales, finance, taxation, logistics, human resources, organization, strategy, management, information systems, entrepreneurship, teaching, etc. (UNIVERSIA, 2016). However, there is no program or clear implementation strategy for a gender approach or mainstreaming in relation to the causes of the phenomenon of the glass ceiling. For this reason, the ultimate goal of our proposal is to design an advocacy plan for the intervention of public education policies from the gender perspective.

The questionnaire conducted among the students in our sample had a section for student's personal and socio-demographic information, as well as a specific section for business and economics-related questions. The demographics of the respondents of the survey were as follows: 113 of the interviewees were students in their last year of their 3-year degree in Business (68.5\%), 35 of students were in their last year of their degree in Management and Business Administration (21.2\%) and 17 students were in their last year of their degree in Economics (10.3\%); 54 were men (32.3\%) and 111 (67.7\%) were women. The average age was 22 years old. The large majority of the students in the Spanish universities (especially in the university selected) are natives and, because of that, we have not considered the nationality of the respondents in the sample. Besides, Parent's Educational level do not show significant differences because most parents do not have university studies. Differences in student participation for each degree are explained by the number of students enrolled in each degree. Later on, the sample was divided into two groups, male and female, in order to report and discuss results of that survey from a gender perspective within Spanish undergraduate programs and therefore within the Spanish society, since almost all the respondents were born in this country.

\subsection{Procedure}

Following the approach of Colander and Holmes (2007), we design a conceptual model which analyzes how different perceptions of the Spanish academic environment could have an influence on the future difficulties faced by women to be promoted to managerial positions related to economic disciplines. These differences are interesting because they help us understand why women are underrepresented in the economics profession and give us insight to what extent the structure of Spanish undergraduate economics education marginalizes women.

In the survey there were 165 respondents and the response rate was about 34 percent of all students enrolled in the economic disciplines described above, approximately the same percentage as the one used by Colander and Holmes $(2007)^{9}$. The researchers explained

\footnotetext{
${ }^{9}$ In Colander and Holmes (2007), the response rate was about 27 percent.
} 
previously to the students the objectives of the research and gave them the appropriate instructions for a right filling of the questionnaire. The survey took students about an hour to complete and was followed up by interviews with students. Generally, 95 percent or more of the students taking the survey answered all the questions.

The data were collected personally at the classroom in presence of the teacher, anonymously and voluntarily. Students were asked to consent to complete it, they were guaranteed anonymity and confidentiality of their answers. Students were randomly chosen among these three degrees in different sessions as volunteers to avoid discouraging students with a task they did not want to perform. In this way, we ensure that responses were consistent and as a result, we checked that almost all of the respondents fulfilled the sample entirely.

In the study, several adjustments were made adapting the American characteristics to the Spanish context. First, the use of American terms in the original sample was adapted to the questions related to Spanish socio-cultural and educational context. Second, the range of values was extended in order to obtain more detailed information. Third, three more questions about interviewees' personal choices were added to the original survey: one was regarding to their choice of university and the other was regarding to their opinion about their potential relocating working, within Spain or abroad.

\subsection{Instrument}

Although the questionnaire model was adapted from the survey of Colander and Holmes (2007), we create a new factorial model from the answers given by students in the sample following a SEM methodology. Structural equation modeling (SEM) encompasses such diverse statistical techniques as path analysis, confirmatory factor analysis, causal modeling with latent variables and even analysis of variance and multiple linear regression. To do so, we first construct our latent variables: one of them referred to the educational profile, favourite subjects, and three of them referred to the professional profile perceived by the students, in particular, professional ambitions, values in workplace and mobility. Table 2 contains the items obtained from the questionnaire that led us to obtain our latent variables. Favourite Subjects construct includes the most preferred subjects of the economics curriculum: competence, development, labour, industrial organization, law and economy and finally regional and urban economy. Professional Ambitions construct includes managerial positions at university, high school and civil servant carreer. Values in Workplace is associated to attitudes towards inclusion of all collectives in the workplace (people with disabilities, dependents and women). Finally, Mobility construct is related to the students preference about working in international assignments as Asia, developing countries or South America. 
Table 2

Constructs: structure and definitions

\begin{tabular}{|c|c|c|}
\hline $\begin{array}{c}\text { Latent } \\
\text { Variable }\end{array}$ & Observable Variable & Item at the Questionnaire \\
\hline \multirow{7}{*}{$\begin{array}{l}\text { Favorite } \\
\text { subjects }\end{array}$} & & $\begin{array}{c}\text { Please, indicate how much you enjoy learning the } \\
\text { next subjects: }\end{array}$ \\
\hline & Competence & Competence \\
\hline & Development & Development \\
\hline & Labour & Labour \\
\hline & Industrial Organization & Industrial Organization \\
\hline & Law and Economy & Law and Economy \\
\hline & Regional \& Urban Economy & Regional \& Urban \\
\hline \multirow{4}{*}{$\begin{array}{l}\text { Professional } \\
\text { ambitions }\end{array}$} & & $\begin{array}{l}\text { Please indicate your level of satisfaction if you } \\
\text { would find in the following situationsin the future: }\end{array}$ \\
\hline & Teaching at the university & Teaching at the university \\
\hline & Teaching at the High School & Teaching at the High School \\
\hline & Politician & Being a Politician \\
\hline \multirow{4}{*}{$\begin{array}{l}\text { Values in } \\
\text { workplace }\end{array}$} & & $\begin{array}{l}\text { Please indicate your agreement with the next state- } \\
\text { ments, related to your behaviour at the workplace: }\end{array}$ \\
\hline & $\begin{array}{l}\text { Support people with dis- } \\
\text { abilities }\end{array}$ & $\begin{array}{l}\text { I will support positive discrimination for people with } \\
\text { disabilities }\end{array}$ \\
\hline & Support dependents & $\begin{array}{l}\text { I will support positive discrimination for people who } \\
\text { has to attend their family }\end{array}$ \\
\hline & Support women & I will support positive discrimination for women \\
\hline \multirow{4}{*}{ Mobility } & & $\begin{array}{c}\text { Please indicate your agreement with the next state- } \\
\text { ments, related to your future job: }\end{array}$ \\
\hline & Asia & I will be willing to move to Asia \\
\hline & Less developed countries & I will be willing to a less developed country \\
\hline & South America & I will be willing to move South America \\
\hline
\end{tabular}

Source: Own elaboration adapted from Colander and Holmes (2007). 
The scale validity of each variable was tested through the Cronbach's Alpha, showing acceptable values $(\alpha>0,7)$ for all constructs and groups (whole, women and men) except the Professional ambitions ${ }^{10}$. For a good reliability of the scale, the Cronbach's Alpha value must be as close to 1 as possible, but values over 0.7 are acceptable. The specific values of the Cronbach's Alpha for each item in each group (the whole group, women and men) are described in Table 3.

Table 3

\section{Constructs structure}

\begin{tabular}{c|c|c|c|c}
\hline Group & Favorite subjects & $\begin{array}{c}\text { Professional } \\
\text { ambitions }\end{array}$ & Values in workplace & Mobility \\
\hline Whole & 0.899 & 0.587 & 0.769 & 0.849 \\
\hline Women & 0.854 & 0.644 & 0.782 & 0.845 \\
\hline Men & 0.948 & 0.467 & 0.756 & 0.857 \\
\hline
\end{tabular}

Source: Own elaboration.

From the results of our study above and considering that applicants' perceptions could predict behavioral outcomes (LaHuis 2007), a lack of external reinforcement and the inadequacy of networking skills in the business environment may be the factors explaining women's self-exclusion from managerial positions in the economic field. For these reasons, we also develop a causal analysis following the System Dynamics methodology that allows us to understand the interaction between internal (psychological) and external (sociological and contextual factors) motives that justify the self-exclusion of women from the managerial positions. Table 4 describes the variables included in this analysis based on the current literature about this phenomena.

Table 4

\section{Description of the variables used in the System Dynamics method}

\begin{tabular}{l|l|l}
\hline \multicolumn{1}{c|}{ Variable } & \multicolumn{1}{c}{ Definition } & \multicolumn{1}{c}{ References } \\
\hline $\begin{array}{l}\text { Expectancies for control of } \\
\text { reinforcements }\end{array}$ & $\begin{array}{l}\text { Women's expectances about } \\
\text { the causal relation between the } \\
\text { academic efforts and the effect of } \\
\text { these efforts in their professional } \\
\text { promotion }\end{array}$ & $\begin{array}{l}\text { Bandura }(1978,1986) \\
\text { Rottter }(1996)\end{array}$ \\
\hline Academic effort & Number of hours of study & \\
\hline
\end{tabular}

${ }^{10}$ This is a not surprising data as it is a quite variable option among university students. 


\begin{tabular}{|c|c|c|}
\hline Self-efficacy perception & $\begin{array}{l}\text { Women's perception about the } \\
\text { causal relation between their } \\
\text { individual academic efforts and } \\
\text { the effect of these efforts in their } \\
\text { professional promotion as women }\end{array}$ & Rottter (1996) \\
\hline $\begin{array}{l}\text { Adaptation of their skills to } \\
\text { the job market }\end{array}$ & $\begin{array}{l}\text { Level of adjustment between the } \\
\text { job profile and the professional } \\
\text { profile of women }\end{array}$ & $\begin{array}{l}\text { DellaVecchio and } \\
\text { Winston (2015) } \\
\text { Eagly and Karau } \\
\text { (2002). }\end{array}$ \\
\hline Behaviours prone to failure & $\begin{array}{l}\text { All behaviours that move women } \\
\text { away from the promotion process }\end{array}$ & $\begin{array}{l}\text { Haslam and Turner } \\
\text { (1995). Rudman and } \\
\text { Glick (2001) } \\
\text { Cuddy et al. (2004) }\end{array}$ \\
\hline Expectations of results & $\begin{array}{l}\text { Women's prospects about their } \\
\text { future promotion }\end{array}$ & Bandura $(1978,1986)$ \\
\hline Sucessful behaviours & $\begin{array}{l}\text { All behaviours that move women } \\
\text { into the promotion process }\end{array}$ & Cuddy et al. (2004) \\
\hline $\begin{array}{l}\text { Abandon their managerial } \\
\text { career }\end{array}$ & $\begin{array}{l}\text { Action of renounce to promotion at } \\
\text { organizations }\end{array}$ & $\begin{array}{l}\text { Agars (2004) } \\
\text { Arfken et al. (2004) } \\
\text { Cuddy et al. (2004) }\end{array}$ \\
\hline $\begin{array}{l}\text { Lack of women's managerial } \\
\text { role models (external rein- } \\
\text { forcement) }\end{array}$ & $\begin{array}{l}\text { Absence of female managers that } \\
\text { serve as reference of professional } \\
\text { goals achievable for women at } \\
\text { organizations. }\end{array}$ & $\begin{array}{l}\text { Powell and Graves } \\
\text { (2003) }\end{array}$ \\
\hline
\end{tabular}

Source: Own elaboration.

\subsection{Data analysis}

The methodology used in this paper includes two methods: a factorial model and a causal dynamic model. First, we run a factorial model that only includes those items that are considered as relevant to build a perceptual profile among students. In other words, from all the items used for the construction of these variables of the model we only selected those that identify the most important (highest weight) as well as significant ( $p<0.05 \%$ ) ones to explain each one of the concepts. From this point, we develop a SEM where the construct Favorite Subjects forms the 'educational profile' of the students and the constructs Profesional Ambitions, Values in Workplace and Mobility form the 'professional profile perceived' (Figure 3). 
Figure 3

Factorial model: description of variables

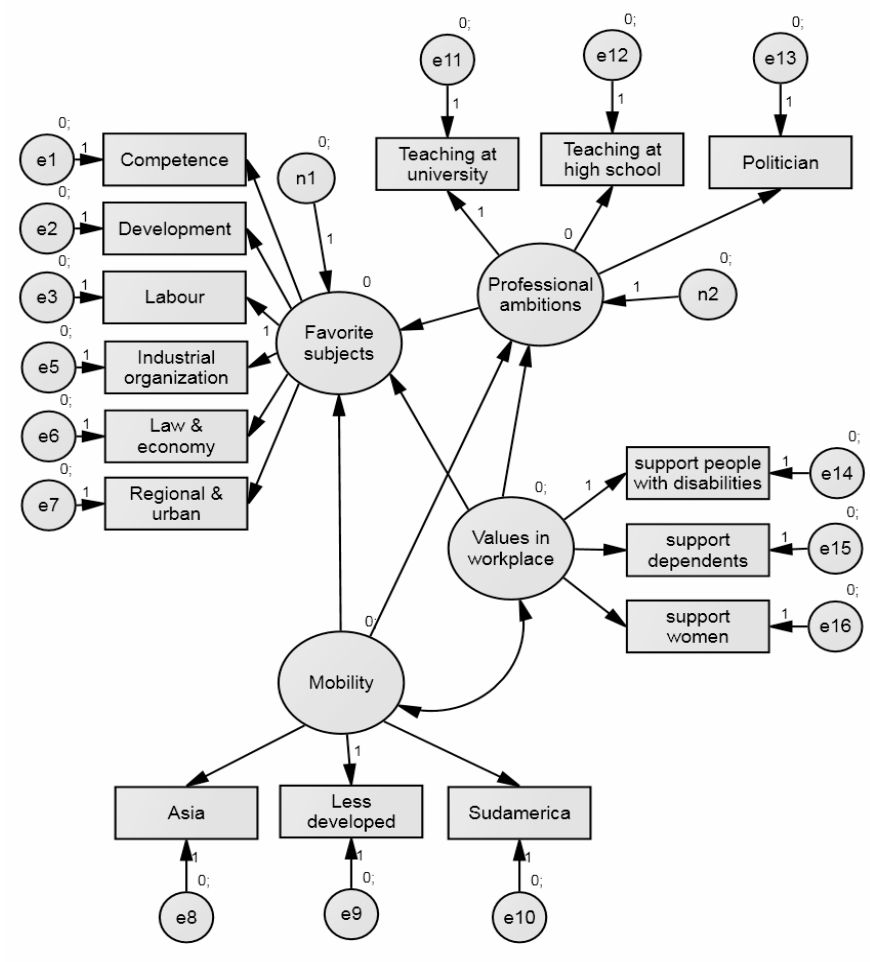

Source: Own elaboration.

The estimation method used for this case has been the maximum likelihood. In Table 5, some of the most common fitting indexes are shown. These indexes are used for comparing the proposed model to the sample data and checking their concordance. The CFI (Comparative Fit Index) aims to compare the proposed model with the worst possible one, trying to find the best approximation to reality, as long as the adjustment improves the null model. The NFI (Normed Fit Index) measures the proportional reduction in the adjustment function when passing to the null model proposed. A very good fit is considered with values close to unity. So, both of them show a better fitting, the closer 1 is their value. The RMSEA (Root Mean Square Error of Approximation) is an absolute measure of adjustment. It determines the amount that the model globally (structural model and measurement model) has capacity for predicting the initial data matrix. It is assumed a good fit for values under 0.05 since an acceptable fit for RMSEA is under 0.08 . 
Table 5

Factorial model: fitting indexes

\begin{tabular}{|c|c|c|c|}
\hline Model & Index & Fitness & \\
\hline \multirow{4}{*}{$\begin{array}{l}\text { Whole } \\
\text { group }\end{array}$} & Chi-squared & 129.892 Freedom degrees $=84$ & Probability $=0.002$ \\
\hline & CFI & 0.955 & \\
\hline & RMSEA & 0.058 & \\
\hline & NFI & 0.885 & \\
\hline \multirow{4}{*}{$\begin{array}{l}\text { Women } \\
\text { group }\end{array}$} & Chi-squared & 134.190 Freedom degrees $=84$ & Probability $=0,000$ \\
\hline & CFI & 0.923 & \\
\hline & RMSEA & 0.074 & \\
\hline & NFI & 0.823 & \\
\hline \multirow{4}{*}{ Men group } & Chi-squared & 125.644 Freedom degrees $=84$ & Probability $=0.002$ \\
\hline & CFI & 0.907 & \\
\hline & RMSEA & 0.098 & \\
\hline & NFI & 0.773 & \\
\hline
\end{tabular}

Source: Own elaboration.

Since future patterns of behaviors are developed during the educational stage, the study of gender differences in both profiles can provide evidences of differences in the real professional role of men and women. According to the following scheme, the model reflects the systemic relations developed between the 'educational profile' (favorite subjects) of students and the 'professional profile perceived' (professional ambitions, values in the workplace and mobility).

This analysis leds us to the next step: the evaluation of how these potential gender differences are behind the self-exclusion of women from top-managerial positions. Thus, attending to these gender differences in the 'professional profile perceived', we describe the behavioral dynamic of self-exclusion of women of managerial positions within the Spanish environment. As a consequence, we formulate the following question: What is the dynamic of the women's self-barriers for assuming managerial positions? In this sense, we describe a dynamic model based on loops of behavior in women that includes external and internal motives through the System Dynamics method. The conception and development of System Dynamics took place during the late 1950's at the MIT in the management field. It is defined as a "rigorous method of system description, which facilitates feedback analysis, usually via a continuous simulation model of the effects of alternative system structure and control policies on system behavior" (Wolstenholme 1983). The results obtained in this model allow us to establish some measures both in the educational and business environment in order to break this women's self-exclusion dynamic. 


\section{RESULTS}

In this section we obtain the results from the two methods used: the SEM model and the System Dynamic model in order to evaluate to what extent the gender differences perceived among the economic undergraduates within the Spanish academic environment will affect and determine the future of the glass ceiling phenomena in this country.

\subsection{Outcomes under the SEM model}

We run the model for the whole group of students, and also for each subgroup of similar gender (male and female students). Table 6 contains the descriptive statistics for the three groups obtaining a good adjustment $(\mathrm{CFI}>0.9)$ in all the models. All items in the questionnaire were presented using a scale between 1 and 5 .

Table 6

SEM Models: descriptive statistics

\begin{tabular}{|c|c|c|c|c|c|c|c|}
\hline \multirow{2}{*}{$\begin{array}{c}\text { Latent } \\
\text { Variable }\end{array}$} & \multirow{2}{*}{$\begin{array}{l}\text { Observable Var- } \\
\text { iable }\end{array}$} & Mean & $\begin{array}{l}\text { Standard } \\
\text { deviation }\end{array}$ & Mean & $\begin{array}{l}\text { Standard } \\
\text { deviation }\end{array}$ & Mean & $\begin{array}{l}\text { Standard } \\
\text { deviation }\end{array}$ \\
\hline & & \multicolumn{2}{|c|}{ Whole group } & \multicolumn{2}{|c|}{ Men } & \multicolumn{2}{|c|}{ Woman } \\
\hline \multirow{6}{*}{$\begin{array}{c}\text { Favourite } \\
\text { subjects }\end{array}$} & Competence & 2.84 & 1.17 & 2.79 & 1.35 & 2.86 & 1.08 \\
\hline & Development & 2.84 & 1.24 & 2.58 & 1.39 & 2.95 & 1.15 \\
\hline & Labour & 3.55 & 1.38 & 3.04 & 1.53 & 3.80 & 1.23 \\
\hline & $\begin{array}{c}\text { Industrial } \\
\text { Organization }\end{array}$ & 2.73 & 1.17 & 2.47 & 1.34 & 2.85 & 1.06 \\
\hline & $\begin{array}{c}\text { Law and Eco- } \\
\text { nomy }\end{array}$ & 2.78 & 1.25 & 2.53 & 1.37 & 2.90 & 1.18 \\
\hline & Regional \& Urban & 2.66 & 1.28 & 2.68 & 1.37 & 2.65 & 1.24 \\
\hline \multirow{3}{*}{$\begin{array}{c}\text { Professional } \\
\text { ambitions }\end{array}$} & $\begin{array}{c}\text { Teaching at the } \\
\text { university }\end{array}$ & 0.36 & 0.83 & 0.32 & 0.83 & 0.38 & 0.83 \\
\hline & $\begin{array}{l}\text { Teaching at the } \\
\text { High School }\end{array}$ & 0.28 & 0.81 & 0.34 & 0.90 & 0.25 & 0.77 \\
\hline & Politician & 0.43 & 0.99 & 0.51 & 1.05 & 0.40 & 0.97 \\
\hline \multirow{3}{*}{$\begin{array}{l}\text { Values in } \\
\text { workplace }\end{array}$} & $\begin{array}{c}\text { Support people } \\
\text { with disabilities }\end{array}$ & 4.42 & 0.87 & 4.15 & 0.95 & 4.55 & 0.81 \\
\hline & $\begin{array}{l}\text { Support depen- } \\
\text { dents }\end{array}$ & 3.89 & 1.21 & 3.98 & 1.15 & 3.85 & 1.24 \\
\hline & Support women & 3.63 & 1.41 & 3.64 & 1.36 & 3.62 & 1.43 \\
\hline
\end{tabular}




\begin{tabular}{cccccccc}
\hline \multirow{3}{*}{ Mobility } & Asia & 2.34 & 1.13 & 2.30 & 1.10 & 2.35 & 1.14 \\
\cline { 2 - 8 } & $\begin{array}{c}\text { Less developed } \\
\text { countries }\end{array}$ & 2.42 & 1.06 & 2.38 & 1.06 & 2.44 & 1.06 \\
\cline { 2 - 8 } & South America & 2.41 & 1.07 & 2.36 & 1.08 & 2.44 & 1.07 \\
\hline
\end{tabular}

Source: Own elaboration.

The outcomes for the whole group indicate that professional ambitions and mobility in the workplace are significant $(\mathrm{p}<0.1)$ to explain the 'educational profile' of the students (Favorite subjects). The results also show that the perception of the importance and capacity to work in different international locations are positively related to higher professional ambitions. Therefore, for the whole group of students, the 'educational profile' is linked to the 'professional profile perceived'. Table 7 and Figure 4 show the values of the regression coefficients and the model outcomes, respectively.

Table 7

Regression coefficients (whole group)

\begin{tabular}{ccccccc}
\hline & & \multicolumn{5}{c}{ Whole Group (CFI 0.955) (RMSEA 0.580) (NFI } \\
Independent & Dependent & \multicolumn{5}{c}{ 0.885) } \\
\cline { 3 - 7 } Construct & Construct & $\begin{array}{c}\text { Estima- } \\
\text { tes }\end{array}$ & $\begin{array}{c}\text { Standarized } \\
\text { Estimates }\end{array}$ & S.E. & C.R. & P \\
\hline Mobility & $\begin{array}{c}\text { Professional_am- } \\
\text { bitions }\end{array}$ & 0.056 & 0.068 & 0.085 & 0.658 & 0.510 \\
\hline $\begin{array}{c}\text { Values in_ } \\
\text { workplace }\end{array}$ & $\begin{array}{c}\text { Professional_am- } \\
\text { bitions }\end{array}$ & 0.194 & 0.117 & 0.165 & 1.173 & 0.241 \\
\hline $\begin{array}{c}\text { Professional__ } \\
\text { ambitions }\end{array}$ & $\begin{array}{c}\text { Favorite_subjects } \\
\text { Mobility }\end{array}$ & -0.318 & -0.197 & 0.177 & -1.802 & 0.072 \\
\hline $\begin{array}{c}\text { Values in_ } \\
\text { workplace }\end{array}$ & Favorite_subjects & 0.226 & 0.171 & 0.118 & 1.916 & 0.055 \\
\hline
\end{tabular}

Source: Own elaboration 
Figure 4

\section{Outcomes: whole group}

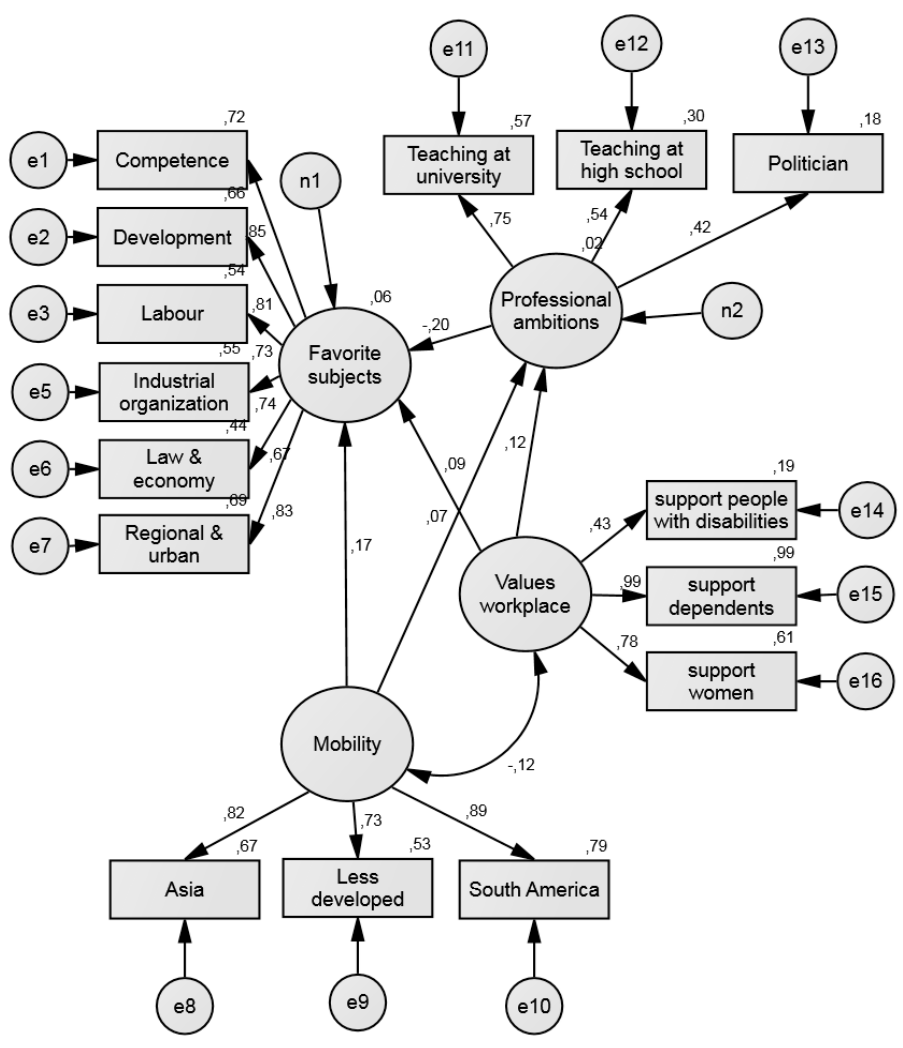

Source: Own elaboration.

Although the 'educational profile' of male and female students looks similar, considering as preferred subjects those related to Regional \& Urban Economy and Competence, the model reflects different outcomes for the subgroups of women and men, regarding the 'professional profile perceived'. This means that male and female students perceive different relations between the items Mobility, Values in the workplace and Professional ambitions.

Female students relate positively their professional ambitions with the existence of favorable values to include all collectives in the workplace, which is consistent with previous research (Brody and Hall 2010). However, their availability for working in international locations (Mobility) is negatively related to their professional ambitions, which is also consistent with previous studies (Altman and Shortland 2008). Table 8 and Figure 5 show the values of the regression coefficients and the model outcomes for the subgroup of female students. 
Table 8

Regression coefficients (women)

\begin{tabular}{ccccccc}
\hline & & \multicolumn{3}{c}{ Women Group (CFI 0.923) (RMSEA 0.740) } \\
\cline { 4 - 6 } $\begin{array}{c}\text { Independent } \\
\text { Construct }\end{array}$ & $\begin{array}{c}\text { Dependent } \\
\text { Construct }\end{array}$ & $\begin{array}{c}\text { Esti- } \\
\text { mates }\end{array}$ & $\begin{array}{c}\text { Stan- } \\
\text { darized } \\
\text { Estimates }\end{array}$ & S.E. & C.R. & P \\
\cline { 3 - 7 } Mobility & $\begin{array}{c}\text { Professional_ } \\
\text { ambitions }\end{array}$ & -0.011 & -0.014 & 0.097 & -0.118 & 0.906 \\
\hline $\begin{array}{c}\text { Values in_ } \\
\text { workplace }\end{array}$ & $\begin{array}{c}\text { Profession- } \\
\text { al_ambitions }\end{array}$ & 0.291 & 0.162 & 0.224 & 1.298 & 0.194 \\
\hline $\begin{array}{c}\text { Profession- } \\
\text { al_ambitions }\end{array}$ & $\begin{array}{c}\text { Favorite_sub- } \\
\text { jects }\end{array}$ & -0.099 & -0.077 & 0.158 & -0.629 & 0.530 \\
\hline Mobility & $\begin{array}{c}\text { Favorite_sub- } \\
\text { jects }\end{array}$ & 0.138 & 0.133 & 0.113 & 1.221 & 0.222 \\
\hline $\begin{array}{c}\text { Values in_ } \\
\text { workplace }\end{array}$ & $\begin{array}{c}\text { Favorite_sub- } \\
\text { jects }\end{array}$ & -0.319 & -0.137 & 0.258 & -1.233 & 0.217 \\
\hline
\end{tabular}

Source: Own elaboration.

Figure 5

Outcomes: women group

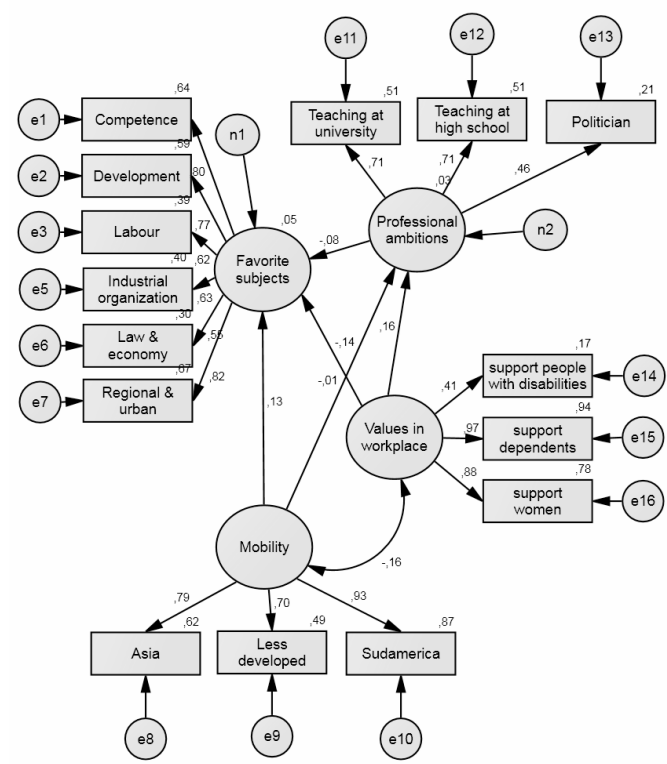

Source: Own elaboration 
On the contrary, male students relate negatively their professional ambitions with the existence of favorable values to the inclusion of all collectives in the workplace. However, the availability for working in international locations (Mobility) is positively related to their professional ambitions. Table 9 and Figure 6 show the values of the regression coefficients and the model outcomes for the subgroup of male students.

Table 9

Regression coefficients (men)

\begin{tabular}{ccccccc}
\hline & Men Group (CFI - 0.907) & (RMSEA 0.098) (NFI 0.773) \\
\cline { 5 - 7 } Independent \\
Construct & $\begin{array}{c}\text { Dependent } \\
\text { Construct }\end{array}$ & Estimates & $\begin{array}{c}\text { Standarized } \\
\text { Estimates }\end{array}$ & S.E. & C.R. & P \\
\hline Mobility & $\begin{array}{c}\text { Professional_- } \\
\text { ambitions }\end{array}$ & 0.138 & 0.221 & 0.133 & 1.043 & 0.297 \\
$\begin{array}{c}\text { Values in_work- } \\
\text { place }\end{array}$ & $\begin{array}{c}\text { Profession- } \\
\text { al_ambitions }\end{array}$ & -0.113 & -0.135 & 0,181 & -0.622 & 0.534 \\
$\begin{array}{c}\text { Professional_am- } \\
\text { bitions }\end{array}$ & $\begin{array}{c}\text { Favorite_sub- } \\
\text { jects }\end{array}$ & -0.771 & -0.304 & 0.588 & -1.311 & 0.190 \\
Mobility & $\begin{array}{c}\text { Favorite_sub- } \\
\text { jects }\end{array}$ & 0.299 & 0.189 & 0.234 & 1.278 & 0.201 \\
$\begin{array}{c}\text { Values in_work- } \\
\text { place }\end{array}$ & $\begin{array}{c}\text { Favorite_sub- } \\
\text { jects }\end{array}$ & 0.972 & 0.458 & 0.359 & 2.706 & 0.007 \\
\hline
\end{tabular}

Source: Own elaboration.

These results are consistent with the idea of women as more socially motivated at work (Mihail 2006) and less ambitious to promote to managerial positions if they include availability for international movements (Altman and Shortland 2008). These results show gender differences regarding to the 'professional profile perceived'. The professional ambitions of the sample of female students are more related with finding social values at the workplace and avoiding mobility. According to Young and Hurlic (2007), job-related self-efficacy will be impacted by person-group fit and will be an influence in career decision making. The 'professional profile perceived' by female students reflects a different labor perspective than their male classmates and it will influence their future perception of self-efficacy.

In general, glass ceiling effect can be caused by 'male-orientated organizational expectations', but in some way it also can be the consequence of women' self-barriers caused for their differential perceptions (less confident, more idealistic and risk averse, among others) especially in managerial job profiles. Then, we can verify the "mismatch hypothesis" underlying the mechanism of gender inequality (e.g., traditional gender roles) in the educational profile that in turn implies gender differences in leadership behavior along the 
future professional career. In other words, the different gender perceptions embeded in the Spanish academic environment deemphasizes women from applied and policy-related economics and, therefore, those perceptions have an influence on the future difficulties faced by women to be promoted to managerial positions.

Figure 6

\section{Outcomes (men)}

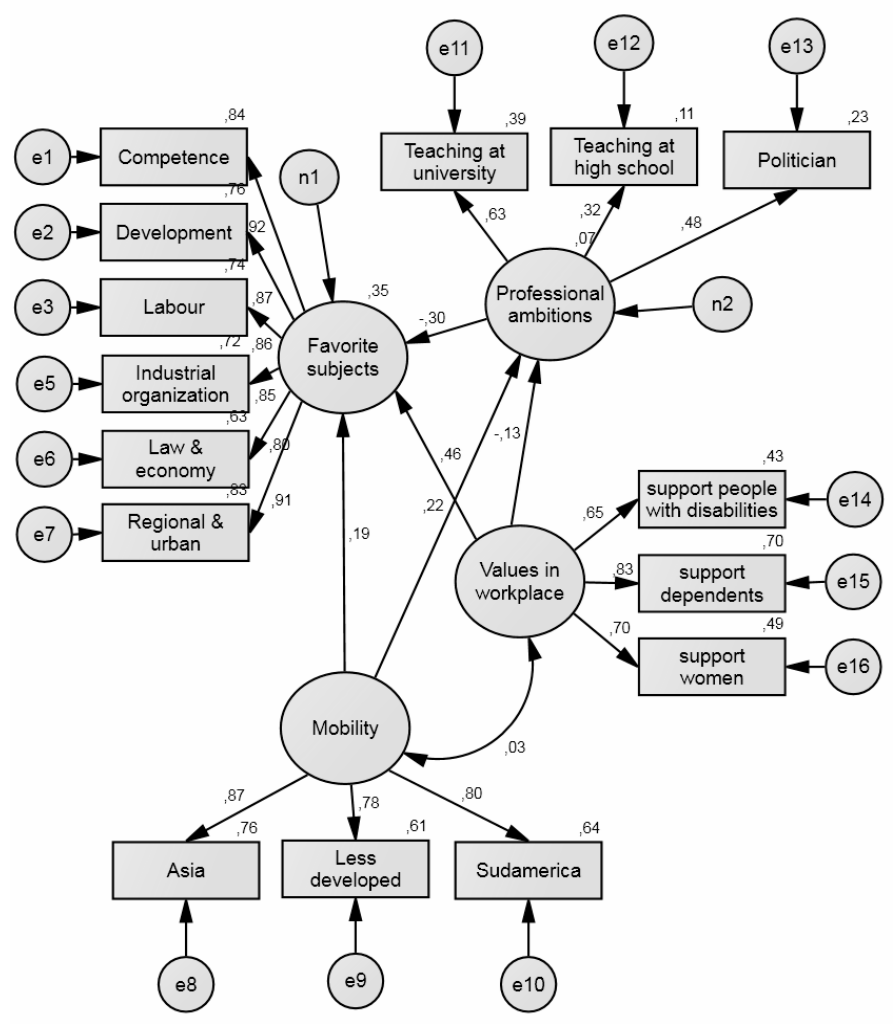

Source: Own elaboration.

\subsection{Outcomes under the Dynamic Systems method}

In this case we raise a causal analysis following the System Dynamics methodology (Stearman 2000) that allows us to understand the relationship between psychological, sociological and contextual factors in the self-exclusion of women of the managerial career ${ }^{11}$. In particular, three loops of behavior were identified in order

\footnotetext{
${ }^{11}$ In the diagrams, the positive sign of the arrows $(+)$ indicates a direct relationship between the variables, while the minus sign (-) shows an inverse relationship between them. The double stripe on the arrow $(/ /)$ indicates a time lag in the relationship between the variables identified.
} 
to analyze in depth how self-exclusion works as a factor which could explain why women choose not to compete against men for managerial positions.

A. Initial expectancies loop (Figure 7). Women's perception of self-efficacy in the workplace is determined by the expectancies for control of reinforcements (Rotter 1966). These expectancies reflect the belief that consequences of behavior are people's responsibility and they are determined by social and intellectual resources and abilities- under internal control- as well as by external reinforcement coming from efficacy perceptions perceived by other people. The self-efficacy perception will also determine outcome expectancies (Bandura 1978; Bandura 1986) meaning that female managers and aspiring managers may believe that certain results may be the consequence of a controlled behavior. The lack of women's managerial role models limits the adaptation of social skills acquired within the academic world to the business environment and therefore reduces women's expectations about the relationship that may exist between their academic effort ('educational profile') and the adaptation of their skills to develop the required professional role ('professional profile perceived'), as compared to male students (Mihail 2006). This perception forces women to make a bigger effort when it comes to academic homework, which has a negative impact on the acquisition of useful social skills within the business environment ${ }^{12}$. Throughout their professional career, women tend to focus on tasks rather than on professional and political networking. Since political skill is related to positive performance ratings in organizations, it can constrain the role expectations for women in organizations (Shaughnessy et al. 2011). This situation can stop their managerial development, perpetuating gender stereotypes.

Figure 7

\section{Initial expectancies loop}

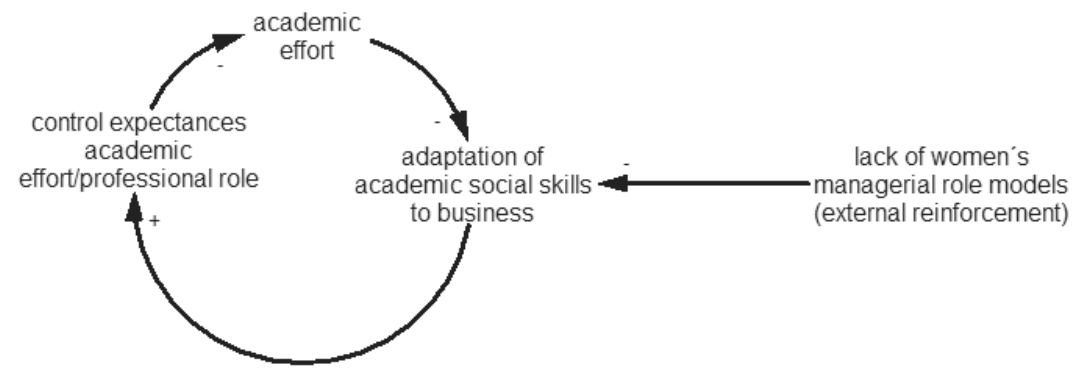

Source: Own elaboration.

12 In fact, our study shows a lower participation of women in sports and volunteering-related activities, as well as a higher dedication to studying, as compared to their male counterparts. 
B. Pre-manager behavior loop (Figure 8). The lack of initial expectancies of the relationship between academic effort and professional skills reduces the women's self-efficacy perception in the workplace, which causes a decrease in expectancies regarding the effect of their actions in relation to the possibility of achieving positive results, limiting behaviors leading to managerial achievements. This situation can create managerial paralysis which reduces successful behaviors (the proactive behavior-results connection is not perceived) and promotes behaviors prone to failure because of the lack of opportunities for taking risks or the lack of initiative in decision-making processes. This pattern could explain the fact that a higher proportion of women abandon their top-positions career, unlike men. A feeling of lower self-efficacy can make women self-exclude themselves when applying to managerial positions. This concept is known as 'concrete ceiling' (Chinchilla y León 2004, p. 9).

Figure 8

\section{Pre-manager behavior loop}

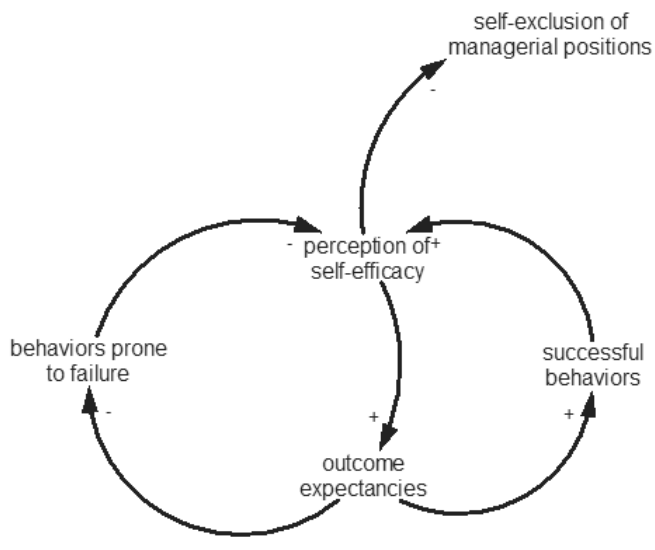

Source: Own elaboration.

As a consequence of the higher number of women abandoning top-level positions, the existence of female role models in these positions is significantly reduced and it consolidates the gender stereotypes which are transmitted to the educational model, perpetuating the aforementioned loops (Figure 9). Furthermore, the stereotypes about female women influence how employees evaluate female manager at workplace (Byron 2008; Burleson 2003).

This analysis brings up a pattern that is difficult to modify. Most of the measures adopted by government institutions are focused on providing women with academic and managerial education as well as establishing quota systems to have women in top-level managerial positions in companies. Even though these measures may be effective shortterm, they may not change the underlying causes of the psychological and social barriers which are preventing women to be regularly promoted to managerial positions in com- 
panies. Therefore, we verify the "stereotype threat" hypothesis under the assumption that women as a group have been stereotyped as being less capable than men and this fact has conditioned their lack of esteem and confidence in order to run for top managerial positions. Finally, we can conclude that the Spanish environment follow the Congruity Theory Model since the self-exclusion of women of the managerial career is due to the interaction of both psychological (internal factors) and sociological (external and contextual factors).

Figure 9

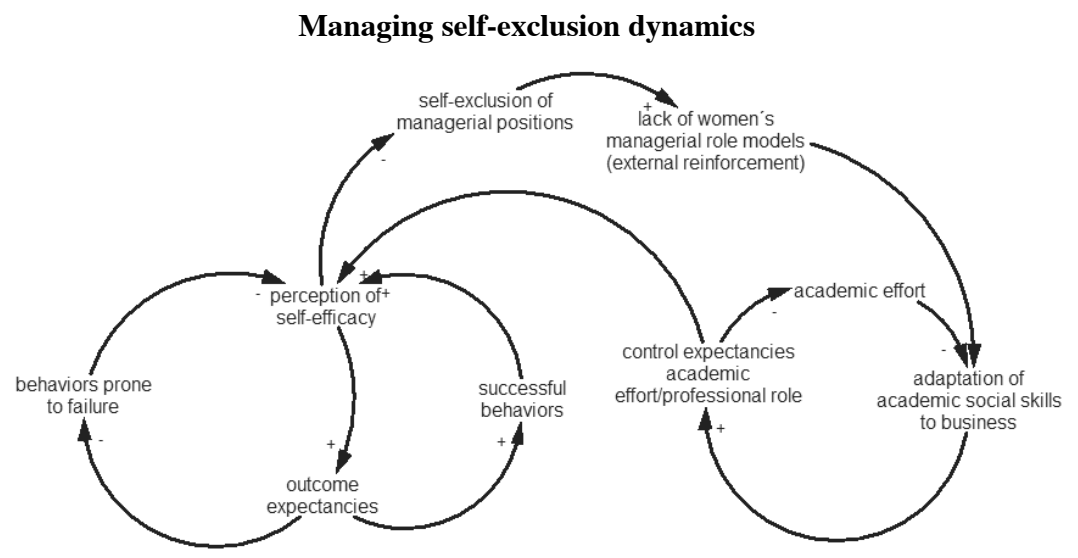

Source: Own elaboration.

\section{GENDER DIFFERENCES AND IMPLICATIONS FOR THE FUTURE: AN EF- FECTIVE PUBLIC POLICY BASED ON EDUCATIONAL MEASURES}

The open debate in Spanish society about make gender equality a priority leads to a series of policy measures and equality laws such as the law related to diversity on boards of directors since 2004, the Spain's Unified Good Governance Code in 2006 which recommended positive discrimination in favor of female members on company boards or, even going beyond this issue, the Gender Equality Act in 2007 that encouraged the greater employment of women by giving preferential treatment to companies with higher female ratios. But it seems that these initiatives have had limited success so far, as several national surveys have recently demonstrated that female managers in Spain do not trust the 2007 law and even think it is ineffective (42\%) and contains no or just a few real changes (ADECCO 2010).

In this sense, despite the wide range of contributions in the field of implementation of public policies, it has not come to establish a broad consensus on the factors that best explain the success or failure of public policy. However, the literature has led to the formation of two theoretical perspectives that are already required to study: the top-down approach 
and the bottom-up approach ${ }^{13}$. At first glance, it seems that these two major explanatory paradigms of the implementation process are irreconcilable, since each relies on very different conceptions of who are the actors most relevant (designers vs. executors), what are the main obstacles for a good implementation (opportunism of the executors vs. the rigidity of a central design) and which are the most appropriate evaluative standards (statutory objectives vs. local values and norms). There have been attempts to reconcile elements of both approaches and provide better explanatory frameworks of the public policy implementation process public. One of the most recognized and cited in literature specialized in the issue is the ambiguity-conflict model proposed by Richard Matland (1995). Its two core elements are, on the one hand, a conflict that raises public policy and, on the other hand, ambiguity both its means and its ends.

Within this scheme, from our point of view, the public policy implementation that better fits to solve the glass ceiling problem is the so called "experimental", that is to say, policies that have a low degree of conflict but a high degree of ambiguity in its means and goals. The decision-making process in this issue is problematic because the objectives are ambiguous, measures are uncertain and the participation of stakeholders is extremely fluid to over time. Therefore, the results of the implementation end up by being very heterogeneous. The most important purpose of a process of experimental implementation is learning instead of the achievement of measurable objectives with preconceived standards. Therefore, it is clear that the "bottom-up" is the most appropriate to understand the experimental implementation.

Along with this, we believe the solution are behind the modification of education policy from a bottom-up perspective through the outcomes and perceptions gathered from the different educational centers in the Spanish environment in order to discover the better policy actions to solve the glass ceiling problem at a central government level. Since gender-related patterns in the educational environment affect the way students develop in their professional profiles, policy makers should encourage the maximization of the intellectual development in the college environment for both sexes (Baxter 1994). Therefore, the role of the public initiative in this educational approach is essential to provide the necessary resources to succeed, not only in an economic way but promotional and cultural through the educational institutions.

Thus, some three educational are proposed in Table 10 to educational institutions in order to reduce the influence of stereotyped gender perceptions in female managers' social and professional environment. These measures are aimed to build a new 'educational profile' that breaks the dynamic future of women self-exclusion of managerial positions.

First, academic institutions should promote the use of successful female role model in case of studies and/or incorporate them in academic training programs, not only as a way to reduce the unemployment rate (McGuinness et al. 2014) but as an example of female performance in the real economic and business administration field. These training programs would reinforce women's self-efficacy perception in the educational and working

\footnotetext{
${ }^{13}$ Theories of implementation have been very prolific in proposing variables to explain such divergent results of various public policies. However, nowadays the explanatory power of these theories has been put into question both the inordinate amount of variables proposed and their implications for the practice of public management. For a further discussion of this topic, see O'Toole (2004).
} 
environment (Cearra Mendialdua et al. 2014). In terms of women management training, new educational programs should reinforce competences such as leadership, learn to learn (based-problem activities), teamwork and communication skills.

Second, the inclusion of educational activities in order to develop social skills adapted to the professional field in three aspects, by using technological platforms widely employed in universities in order to foster networking skills applied to business. Among students, it would be necessary to develop volunteers programs like DIT programs or informal team programs like outdoors. Among students and teachers the main proposals are the creation of business games with women as leaders combining with the inclusion of them as assistants in business projects leaded by teachers. These activities, since simulating real managerial environments, reinforce the decision process skills in women. Among students and business professionals we propose the presence of 'godfather system' to support the managerial career of female students and 'business angels' to bring real practices into the classes and serve as future investors for women entrepreneurs.

Table 10

Educational measures avoiding women' self-exclusion at work

\begin{tabular}{|c|c|c|}
\hline Entrepreneurial competences & $\begin{array}{l}\text { Educational } \\
\text { activities }\end{array}$ & $\begin{array}{l}\text { Coaching } \\
\text { programs }\end{array}$ \\
\hline $\begin{array}{l}\text { Successful role models (case } \\
\text { studies) } \\
\text { Management training }\end{array}$ & $\begin{array}{l}\text { Among students: volunteers programs } \\
\text { and informal team programs } \\
\text { Among students and teachers: female } \\
\text { assistants in business games and } \\
\text { projects } \\
\text { Among students and business profes- } \\
\text { sional: godfather system and business } \\
\text { angels }\end{array}$ & $\begin{array}{c}\text { Academic coaching } \\
\text { programs } \\
\text { Job coaching pro- } \\
\text { grams } \\
\text { Mentoring }\end{array}$ \\
\hline
\end{tabular}

Source: Own elaboration.

Third, we propose coaching programs in academic and job environments. Coaching leads to the effective generation of objectives and goals, behavior patterns and proactive action plans to get successful women managerial profiles. These programs also include motivational resources as well as specific work of self-esteem and self-confidence. Previous research points out that following positive feedback, individuals who score low on self-steem will have more pronounced affective relations than individuals who score higher on self-esteem, because those low in self-esteem are in greater need for self-enhancement (Illies et al. 2007). In the case of female students, these programs can be aimed to reinforce their self-esteem for future work assignments. In particular, academic coaching programs (at the university) pretend to better promote networking between students and businesses. In the same way, job coaching systems (outside the university) pursue to match students' professional skills to job opportunities. 
Mentoring is another important measure to reduce barriers to women's career advancement and provide women less psychosocial support (Cullen and Lunab 1993). Despite these solutions are well known, we propose to adapt mentoring activities to the obstacles shown in Figure 9. In this sense, a tutorial action program (TAP) has been developed among students at the University of A Coruña with very good results in terms of women's motivation, confidence and self-efficacy perception.

All these educational measures suggest a different approach to the study of barriers preventing women to be promoted to managerial positions and may also contribute to avoid the underlying causes of women's self-exclusion from these positions.

\section{CONCLUSIONS}

This study advances the reasons explaining the different gender roles and the roots of inequality in managerial employment for women in Spain within the current crisis from a multiple perspective. In particular, our proposal is based on the analysis of the gender differences of perception of the 'educational profile' and 'professional profile perceived' as well as its impact on the self-exclusion dynamics in the workplace. We adapted the conceptual framework of Colander and Holmes (2007) in order to analyze gender differences observed in 165 Spanish economic undergraduates of the last promotion of the Faculty of Economics and Business Administration of University of A Coruña (Spain), before the change of the curriculum design for studies in Economy required for the European Space of Higher Education, through the exploration of gender differences perceived on several factors: the educational profile (favorite subjects) and the professional profile perceived (professional ambitions, values associated to the workplace and mobility). A factorial model based on a SEM model explores these perceptual differences between male and female students. The outcomes for the whole group show that professional ambitions and mobility disposition are significant to explain the 'educational profile' of the students. The results also show an educational system biased by gender and reveal that while the professional ambitions of female students are more related with finding social values at the workplace, avoiding mobility, their male classmates show a higher disposition to work in international assignments. Women also consider the values associated to social exclusion as a limitation for their professional ambitions.

Attending to these gender differences in the 'professional profile perceived', we also describe the behavioral dynamic of self-exclusion of women of managerial positions through the System Dynamics model considering both external reasons (gender stereotypes or organizational policies) and internal ones (self-confidence, self-esteem). Findings confirm a consolidation of the gender stereotypes that are transmitted to the educational model, which perpetuates the dynamic of self-exclusion. In order to break such dynamic, we propose a bunch of educational measures suggested for Spain by using the "experimental" implementation in public policies under a scheme bottom-up in order to find a different approach to the study of barriers preventing women to be promoted to managerial positions (since the policy measures carried out recently in Spain barely have had the impact pursued in gender equally). 
The novelty of this study is based on the explanation of this effect as a consequence of gender differences observed in the educational profile and professional profile perceived by students Similarly, it is equally innovative the interaction between external and internal reasons to justify why women are still far from reaching senior management positions through two different methodologies that provide a new perspective in the study of the so-called glass ceiling. This complex analysis led us to verify the three hypotheses made in the paper. First, the "mismatch" hypothesis that verifies the different gender perceptions in education profile and professional profile. Second, the "stereotype threat" hypothesis under the assumption that women as a group have been stereotyped as being less capable than men and this fact has conditioned their lack of esteem and confidence in order to run for top managerial positions. Third, we can conclude that the Spanish environment follows the Congruity Theory Model since the self-exclusion of women of the managerial career is due to the interaction of both psychological (internal factors) and sociological (external and contextual factors). Therefore, educational measures proposed in this research are a starting point to implement public policies which could reduce women's barriers to break the glass ceiling.

However, we must consider some limitations of the paper. Empirical evidence on students' perceptions of gender roles and how these roles might influence their career aspirations are relevant but the generalizability of our results is also restricted. On the one hand, our results must be interpreted within the context of the Spanish university system where universities are primarily state-run (hence affordable) and it is easier for students to be accepted in the degrees mentioned above, unlike top US universities where the idea of being accepted in some university can lead students to high stress and pressure, especially in women. On the other hand, the claims of the article are just delving into the environmental and local conditions surrounding students, since its incorporation into the education system until they complete their university studies. The large majority of the students in the Spanish universities (especially in the university selected) are native and, because of that, we have not considered the nationality of the respondents in the sample. The results, therefore, cannot be extended internationally. Further research would be necessary to expand this study in the future by interviewing students in other universities with the goal of applying this research to other educational environments. Moreover, extended studies among different countries and realities are needed to validate a general approach from different business and educational models.

\section{ACKNOWLEDGEMENTS}

The third author gratefully thanks the financial support from the Xunta de Galicia (Spanish Regional Government) through Grant EM2014/051. The usual disclaimer applies.

\section{REFERENCES}

ADECCO, 2010. Las directivas españolas pierden la confianza en la Ley y el Ministerio de Igualdad. Madrid: Adecco, IV Adecco Survey.

Agars, M. D., 2004. Reconsidering the impact of gender stereotypes on the advancement of women in organizations. Psychology of Women Quarterly, 28 (2), 103-111. 
Alemagno S. and Dickie J., 2005. Employment issues of women in jail. Journal of Employment Counseling, 42 (2), 67-74.

Altman Y. and Shortland S., 2008. Women and international assignments: taking stock. A 25-year review. Human Resource Management, 47 (2), 199-216.

Anastasia T. T., Tremblay J., Kenneth R., Makela C. J. and Drennen N. H., 1999. Student gender differences in perceived importance of college services. College Student Journal, 33 (2), 206-210.

Arfken D. E., Bellar, S. L. and Helms, M. M., 2004. The ultimate glass ceiling revisited: The presence of women on corporate boards. Journal of Business Ethics, 50 (2), $177-186$.

Bandura, A., 1978. Reflections on self-efficacy. In Rachman, S. J. ed. Advances in behavior research and therapy. Oxford: Pergamon, 237-269.

Bandura, A., 1986. From thought to action: Mechanisms of personal agency. New Zealand Journal of Psychology, 15 (1), 1-17.

Barrientos, S., 2001. Gender, Flexibility and Global Value Chains. IDS Bulletin, 32 (3), 83-93.

Baxter Magolda, M. B., 1992. Knowing and reasoning in college: Gender related patterns in students' intellectual development. $1^{\text {st }}$ ed. San Francisco, CA: Jossey-Bass.

Blickenstaff, J. C., 2005. Women and science careers: leaky pipeline or gender filter? Gender and Education, 17 (4), 369-386.

Bradley, K., 2000. The incorporation of women into higher education: Paradoxical outcomes? Sociology of Education, 73 (1), 1-18.

Brody, L. R. and Hall, J. A., 2010. Gender and emotion. In: Lewis, M. and Haviland, J. M., ed. Handbook of Emotions. New York: Springer, 429-454.

Burleson, B. R., 2003. The experience and effects of emotional support: What the study of cultural and gender differences can tell us about close relationships, emotion, and interpersonal communication. Personal Relationships, 10 (1), 1-23.

Byron, K., 2008. Differential effects of male and female managers' non-verbal emotional skills on employees' ratings. Journal of Managerial Psychology, 23 (2), 118-134.

Chinchilla, N. and León, C., 2004. La ambición femenina. Cómo re-conciliar trabajo y familia. $1^{\text {st }}$ ed. Madrid: Aguilar.

Colander D. and Holmes J., 2007. Gender and graduate economics education in the US. Feminist Economics, 13 (2), 93-116.

Conner, K.R., 1991. A historical comparison of resource-based theory and five schools of thought within industrial organization economics: do we have a new theory of the firm? Journal of Management, 17 (1), 121-154.

Cotter D.A.M., Hermsen J.M., Ovadia S. and Vanneman, R., 2001. The Glass Ceiling Effect. Social Forces, 80 (2), 655-681.

Cuddy A. J. C., Fiske S. T. and Glick, P. 2004. When professionals become mothers, warmth doesn't cut the ice. Journal of Social Issues, 60 (4), 701-718.

Cullen D. L. and Lunab G., 1993. Women Mentoring in Academe: addressing the gender gap in higher education. Gender and Education, 5 (2), 125-137.

Daley, D. M., 1996. Paths of glory and the glass ceiling: differing patterns of career advancement among women and minority federal employees. Public Administration Quarterly, 20 (2), 143- 162. 
DellaVecchio D. and Winston B.E., 2015. A seven-scale instrument to measure the Romans 12 motivational gifts and a proposition that the Romans 12 gift profiles might apply to person-job fit analysis. International Journal of Leadership Studies, 9 (1), 1-22.

Eagly A. H. and Karau S. J., 2002. Role congruity theory of prejudice towards female leaders. Psychological Review, 109 (3), 573-598.

Eccles, J.S., 1994.Understanding women's educational and occupational choices: applying the

EUROPEAN COMMISSION, 2013. Women and men in leadership positions in the European Union 2013. Belgium: Directorate-General for Justice.

Fernández Enguita, M., 2004. Las desigualdades ante la educación: Una herida que no cierra. In: Carbonell Sebarroja, J. and Gimeno Sacristán, J., eds. El sistema educativo. Una mirada crítica. Barcelona: Cuadernos de Pedagogía, 44-51.

García-Retamero R. and López-Zafra E., 2009. Causal attributions about feminine and leadership roles: a cross-cultural comparison. Journal of Cross-Cultural Psychology, 40 (3), 492-509.

González-González J.M., Bretones F.D., Zarco V. and Rodríguez A., 2011. Women, immigration and entrepreneurship in Spain: A confluence of debates in the face of a complex reality. Women's Studies International Forum, 34 (5), 360-370.

González Pérez, T., 2010. Mujeres, Educación y Democracia. Revista de Educación, 351, 337-359.

Graf, V. 2005, September 2. Study habits, co-curricular involvement in college varies by gender. The Daily Evergreen. Retrieved June 5, 2006, from: http:// www.dailyevergreen. com/disp_story.php? storyId=14094.

Grant, R.M., 1996. Toward a knowledge-based theory of the firm. Strategic Management Journal, 17 (52), 109-122.

Hair J. F., Anderson, R. E., Tatham, R. L. and Black, W. C., 1998. Multivariate data analysis. $1^{\text {st }}$ ed. New Jersey: Prentice Hall.

Haslam S. A. and Turner J. C., 1995. Context-dependent variation in social stereotyping 3: Extremism as a self-categorical basis for polarized judgment. European Journal of Social Psychology, 25 (3), 341-371.

Hernández-Bark A. S., Escartín, J. and van Dick R., 2014. Gender and leadership in Spain: A systematic review of some key aspects. Sex Roles, 70 (11-12), 522-537.

Hymowitz C. and Schellhardt T. D., 1986, The Glass Ceiling, sec. D1, 4-5, A Special Report on The Corporate Woman, The Wall Street Journal, March 24, 1986, 1.

Illies R., De Pater I.E. and Judge T., 2007. Differential affective reactions to negative and positive feedback and the role of self-esteem. Journal of Managerial Psychology, 22 (6), 590-609.

Jöreskog K.G. and Sörbom D., 1982. Recent developments in structural equation modeling. Journal of Marketing Research, 19 (4), 404-416.

Joy L., Carter N.M., Wagner H.M. and Narayanan S., 2007. The bottom line: Corporate performance and women's representation on boards. New York: Catalyst.

Kiaušienė I. and Streimikiene D., 2013. The assessment of differences of women's and men's status in the labour market. Transformations in Business and Economics, 12 (2), 125-137. 
Killeen L.A., López-Zafra E. and Eagly A.H., 2006. Envisioning oneself as a leader: comparisons of women and men in Spain and the United States. Psychology of Women Quarterly, 30 (3), 312-322.

LaHuis D.M., MacLane C.N. and Schlessman B. R., 2007. Do applicants' perceptions matter? Investigating reapplication behavior using fairness theory. International Journal of Selection and Assesment, 15 (4), 383-393.

Law 3/2007. Ley Orgánica 3/2007, de 22 de marzo, para la Igualdad Efectiva de Mujeres y Hombres. Boletín Oficial del Estado (Spain) núm. 71, Friday March 23th 2007.

Levin, B., 2003. Education and Training Policy Division. Canada: OECD for the Equity in Education Thematic Review, Education and Training Policy Division, 52.

Loderstedt, K., 2005. East German women in management. Women in Management Review, 20 (5), 329-344.

Martínez Gómez J., Botero Escobar N.E. and Saldarriaga Ríos J.G., 2010. Características sociodemográficas de estudiantes universitarias y sus percepciones acerca de la equidad de género en Educación Superior. Revista Virtual Universidad Católica del Norte, $30,1-22$.

Matland, R.E., 1995. Synthesizing the Implementation Literature: The Ambiguity-Conflict Model of Policy Implementation. Journal of Public Administration Research and Theory, 5 (2), 145-174.

Matsa D. A. and Miller A. R., 2013. A female style in corporate leadership? Evidence from quotas. American Economic Journal: Applied Economics, 5 (3), 136-169.

McGuinness S., O'Connell P. J. and Kelly E., 2014. The Impact of Training Programme Type and Duration on the Employment Chances of the Unemployed in Ireland. The Economic and Social Review, 45 (3), 425-450.

Mehta C.M., Keener E. and Shrier L., 2013. Perceiving advantages and disadvantages of being a female graduate student in the US and the UK. Gender and Education, 25 (1), 37-55.

Mendialdua J.C., Orizaola Iniesta P.M. and Jiménez López M., 2014. Utilización de la lógica borrosa en la selección de personas e ideas para la participación en programas públicos de ayuda a la creación de empresas. Cuadernos de gestión, 14 (2), 73-98.

Mihail, D.M., 2006. Women in management: gender stereotypes and students' attitudes in Greece. Women in Management Review, 21 (8), 681-689.

Molero Alonso F., Cuadrado Guirado I., García Ael C. Recio Saboya P. and Rueda Laffont B. 2009. Mujer y liderazgo en el siglo XXI: una aproximación psicosocial a los factores que dificultan el acceso de la mujer a los puestos de alta responsabilidad. Madrid: Instituto de la Mujer, Secretaría General de Igualdad.

Morrison A.M. and von Glinow M.A., 1990. Women and Minorities in Management. American Psychologist, 45 (2), 200-208.

OECD, 2012. Gender equality in education, employment and entrepreneurship: final report to the MCM. Paris: Meeting of the OECD Council at Ministerial Level, C/MIN 5.

O'Toole, L.J., 2004. The Theory-Practice Issue in Policy Implementation Research. Public Administration, 82 (2), 309-329.

Powell, G.N., 1980. Career development and the woman manager: A social power perspective. Personnel, 57 (3), 22-32. 
Reskin, B.F. and Roos, P.A., 1990. Job queues, gender queues: Explaining women's inroads into male occupations. $1^{\text {st }}$ ed. Philadelphia, PA: Temple University Press.

Reskin B.F. and McBrier D.B., 2000. Why Not Ascription? Organizations' Employment of Male and Female Managers. American Sociological Review, 65 (2), 210-233.

Ridgeway, C.L., 2001. Gender, status, and leadership. Journal of Social Issues, 57 (4), $637-$ 655.

Rosener, J. B., 1995. America's Competitive Secret: Utilizing Women as a Management Strategy. $1^{\text {st }}$ ed. New York: Oxford University Press.

Rottenberg, C., 2014. Happiness and the Liberal Imagination: How Superwoman Became Balanced. Feminist Studies, 40 (1), 144-168.

Rotter, J.B., 1966. Generalized expectancies for internal versus external control of reinforcements. Psychological Monographs, 80 (1), 1-28.

Rudman L.A. and Glick P., 2001. Prescriptive gender stereotypes and backlash toward agentic women. Journal of Social Issues, 57 (4), 743-62.

Rumelt, R.P., 1987. Theory, strategy and entrepreneurship. In: Teece, D. ed. The competitive challenge: strategies for industrial innovation and renewal. Cambridge, MA: Ballinger, 137-158.

Ryan M.K., Haslam S.A., Hersby M.D., and Bongiorno, R. 2011. Think crisis-think female: The glass cliff and contextual variation in the think manager-think male stereotype. Journal of Applied Psychology, 96 (3), 470-489.

Shalev, M., 2009. Class Divisions of Women. In: Gornick, J.C. and Meyers, M.K., eds. Gender Equality. London: Verso Publishers, Vol.VI.

Shaughnessy B.A., Treadway D.C., Breland J.A., Williams L.V., Brouer R.L., 2011. Influence and promotability: the importance of female political skill. Journal of Managerial Psychology, 26 (7), $584-603$.

Stearman J.D., 2000. Business Dynamics: Thinking and Modeling for a Complex World. $1^{\text {st }}$ ed. London: Irwin, McGraw-Hill.

UDC, 2010. Informe de Inserción Laboral de Graduados da UDC Curso 2009/2010. A Coruña: Observatorio de la UDC.

UNIVERSIA, 2016. Grado en administración y dirección de empresas. Madrid: Universia.

Ventura Fernández R. and Quero Gervilla M..J., 2013. Factores explicativos de la intención de emprender en la mujer. Aspectos diferenciales en la población universitaria según la variable género. Cuadernos de Gestión, 13 (1), 127-150.

Wajcman, J., 1998. Managing Like a Man: Women and Men in Corporate Management. $1^{\text {st }}$ ed. Michigan: Pennsylvania State University Press.

Wright, S., 1921. Correlation and causation. Journal of Agricultural Research, 20, 557585.

Wolstenholme, E.F., 1983. System Dynamics: a system methodology or a system modelling technique. Dynamica, 9, 84-90.

Young A. M. and Hurlic D., 2007. Gender enactment at work. The importance of gender and gender-related behavior to person-organizational fit and career decisions. Journal of Managerial Psychology, 22 (2), 168-187. 
